\title{
Factors Affecting Employees' Preference to Pay Zakat: Case of Amil Zakat Institution of Bogor Agricultural University
}

\author{
Yekti Mahanani \\ International Islamic University Malaysia, Malaysia \\ Tanti Novianti and Ranti Wiliasih \\ Bogor Agricultural University, Indonesia \\ Salina Hj Kassim \\ International Islamic University Malaysia, Malaysia \\ Paper to be presented at International Conference of Zakat 2018 \\ 15-16 November, Universitas Gadjah Mada, Yogyakarta, Indonesia
}

\section{ABSTRACT}

The aim of the Indonesian Government Regulation No 14/2014 is to assist the national zakat agency - BAZNAS in zakat collection by forming zakat collector units in government institutions such as in higher learning institutions' campusses. The Zakat Collector Unit of Amil Zakat Institution of Bogor Agricultural University (LAZ IPB) has been established for this reason in 2003, however despite being in existence for quite a while, its development has been rather slow. The aim of this study is to explore the potential issues on income zakat and determine factors affecting the employees to pay income zakat using the service of LAZ IPB. Data collection was conducted during the period from $1^{\text {st }}$ April 2014 to $7^{\text {th }}$ June 2014. In methodology, the study adopted the Logistic regression technique to analyze the factors affecting the employees to pay zakat with LAZ IPB. The findings showed that two factors, namely service and income level were significant in influencing the employees to pay their income zakat with LAZ IPB. Demographic factors such as occupation and gender are also affecting the preference of employees to pay zakat in LAZ IPB.

Keywords: Amil Zakat Institution (LAZ), preference, logistic regression, income zakat

\section{INTRODUCTION}

In the context of an Islamic economy, zakat is an important instrument in improving the welfare of the community. The success methods of the Prophet Muhammad (pbuh) in establishing prosperous Muslim community relied very much on the Islamic third sector including zakat, infaq, and sadaqah. After the hijrah (movement) of the Prophet to Medina, zakat served essential functions as both an act of worship and major source of income for the country. The Prophet even gave examples and instructions to the management of zakat to send officers to collect and distribute zakat outside the city of Medina (Qardhawi, 1993).

In Indonesia, the National Board of Zakat (BAZNAS) is a national zakat institution entrusted to manage zakat as specified under the Law No. 23/ 2011 established by Government of Indonesia. BAZNAS is authorized to manage and distribute zakat at both the national and regional levels. Consequently, BAZNAS faces a great challenge to ensure effective implementation of its responsibility in view of the vast geographical area of the country.

Various efforts have been undertaken to continuously improve zakat in all aspects. First, strengthening the regulation on zakat through efforts to 
accelerate the implementation of Law no. 23/2011 on the Management of Zakat. Beik (2013) argues that a post-judicial review of Law no. 23/2011 would strengthen the political character of zakat by closely linking it to the role of government. This is very important as a prerequisite for the strengthening of national zakat management system currently developed by BAZNAS as the coordinator of national zakat management. Second, optimizing zakat collection to reduce the gap between zakat potentials which reaches 217 trillion rupiah compared with its actual collection. In this regard, the Government of Indonesia plans to ensure that ministers and state officials, as well as employees of government-linked companies (BUMN) and civil servants to fulfill their obligations to pay zakat on income through the support of BAZNAS.

Income zakat is one type of contemporary zakat that belonging to the household zakat. Yusuf Qardhawy (1993) states that income that derived from professional worker or salary that is earned through his expertise, either done individually or jointly can be included into obligatory of zakat.Menwhile, obligation to pay income zakat for Muslim has been agreed upon by international Muslims in the International Congress of Zakat I, in Kuwait at 29 Rajab $1404 \mathrm{H}$ (April 30, 1984). In Indonesia, Law No. 23/2011 about Zakat Management Chapter IV clause 4 also explicitly mentioned that revenues and services is also categorized as zakat properties. In addition, Government Law No 14/2014 also stated that because the implementation of duties and functions about zakat, BAZNAS, Provincial BAZNAS, and regional BAZNAS can establish zakat collection unit institution to assist the collection of zakat. The collection of zakat through zakat collection unit is mentioned explicitly in Article 54 Para. 2 can be done by establishing zakat collection unit in universities to collect income zakat from employees salary.
The issuance of regulation on zakat has encouraged the development of zakat institution and amil zakat institution (LAZ) managed by community. Bogor Agricultural University (IPB) is one of public university which has amil zakat institution (LAZ) as non-structural institution for collecting and dictributing zakat since 2003. It was validated through the Rector Decision Letter No. 085/K13/KEP/2003. Amil Zakat Institution of Bogor Agricultural University (LAZ IPB) incorporated as Zakat Collecting Unit (UPZ) of National Board of Zakat (BAZNAS) based on BAZNAS's Chairman Decision No. 016/BP/BAZNAS/VIII/2012. Based on the Book of Employees in IPB 2012 stated that the number of IPB employees who are Muslims and have income more than or equal to 3.1 million rupiah is 2044 people with its detail, 1074 people are educators (lecturers) and 970 people are educational staff. Meanwhile, data of muzakki from Amil Zakat Institution of Bogor Agricultural University (LAZ IPB) that also employees of Bogor Agricultural University in 2013 is 315 people. The monthly average of Zakat acceptance in LAZ IPB is approximately 50 millions rupiahs from its potency about 200 millions rupiahs (LAZ IPB, 2014). This becomes an interesting phenomenon to be studied because for 10 years standing of LAZ IPB, it has participation rate only about $15 \%$ from IPB's employees.

This study aims to investigate the determining factors affecting zakat behaviour of employees in Bogor Agricultural University (IPB). Specifically, the study attempts to provide empirical evidences on the factors influencing preference of IPB's employees in paying zakat through the LAZ IPB. 


\section{LITERATURE REVIEW}

\section{Potentials of Zakat in Indonesia}

Zakat has high potentials to be utilized to address the problem of poverty in Indonesia (Wibisono, 2010). A study from BAZNAS and the Faculty of Economics and
Management, Bogor Agricultural University (FEM IPB) in 2011 shows that national zakat potentials in Indonesia is 217 trillion rupiahs or an equivalent of $3.4 \%$ of the country's Gross Domestic Product (GDP). Table 1 below shows national zakat potential in Indonesia.

Table 1. The National Zakat Potentials

\begin{tabular}{|c|c|c|c|}
\hline No & Type of zakat & $\begin{array}{l}\text { Zakat Potentials } \\
\text { (trillions rupiahs) }\end{array}$ & $\begin{array}{c}\text { Percentage of GDP } \\
(\%)\end{array}$ \\
\hline 1 & Household Zakat's Potentials & 82.7 & 1.30 \\
\hline 2 & $\begin{array}{l}\text { Zakat of Private Industry's } \\
\text { Potentials }\end{array}$ & 114.89 & 1.80 \\
\hline 3 & $\begin{array}{l}\text { Zakat Government Linked } \\
\text { Company's Potentials }\end{array}$ & 2.4 & 0.04 \\
\hline \multirow[t]{2}{*}{4} & Savings Zakat Potentials & 17 & 0.27 \\
\hline & Total Potentials of National Zakat & 217 & 3.40 \\
\hline
\end{tabular}

Source: Research of BAZNAS and IPB (2011) in Potensi Zakat Nasional (2013).

Despite the bright prospects of zakat, the collection of zakat by BAZNAS is just about $1 \%$ from all national zakat potentials (Ministry of Religious Affairs, 2013). This hampers the realization of zakat as an important tool for poverty alleviation in Indonesia. The potentials of zakat is far from being realized mainly due to two factors. First, the behavior of muzakki (zakat payers), which is still short-term oriented, interpersonal, with low awareness, to pay zakat through institution (Fatah, 2006). Second, the transparency and credibility of zakat management institutions is still not optimal, therefore, the trust of the public towards zakat institutions is still low (Beik and Mukhlis, 2012).

It is encouraging to note, however, that there is an increasing trend in the zakat collection by BAZNAS (Table 2). This essentially indicates the increasing public awareness to pay zakat through the institution in Indonesia. Therefore, it is highly important to explore and determine the critical factor that are relevant in affecting muzakki's preference to pay zakat in the Amil zakat institutions, to complement the effort of BAZNAZ in increasing the collection of zakat, which is currently way below its potentials.

Table 2. Development of National Zakat Acceptance/Collection

\begin{tabular}{ccc}
\hline Year & $\begin{array}{c}\text { Amount of Collection } \\
\text { (trillions rupiahs) }\end{array}$ & $\begin{array}{c}\text { Growth } \\
(\%)\end{array}$ \\
\hline 2010 & 1.5 & - \\
2011 & 1.73 & 15.33 \\
2012 & 2.2 & 27.16 \\
2013 & 2.5 & 13.63 \\
\hline
\end{tabular}

Source: BAZNAS 2014 (processed) 
Income Zakat: Concept, Applications and Related Issues

Qardhawi (1993) argues that the most appropriate equivalent of zakat law is zakat al-mustafad (the treasure obtained through a new and lawful type of ownership). The types of al-mal al-mustafad including alamalah, income earned in the form of wages or salaries for a particular job; al'atiyah, a kind of fixed bonus or incentive that is regularly received by Islamic state warriors from the baitul mal; al-mazalim, the kind of property confiscated illegally by the previous ruler, and has been deemed lost by the original owner. If the property is returned to the original owner, then the property is categorized as property acquired with new ownership, therefore zakat must be paid. Therefore, zakat is the zakat collected/ earned from wage/ salary/ honorarium employees and professional business such as income of a doctor, engineer, teacher, advocate, artist, tailor, and others who have reached nisab.

Obligation to pay zakat also regulates in Law No. 23/2011 about Zakat Management, Article 4, Para. 2.(h) (incomes and services belonging to zakat mal). Thus, the provisions of this Act become breakers of dissent that exists, because there is a rule that states: hukmul wali yarfa'ul khilaf, which means provisions of the ruler / law to eliminate differences (opinions). The basis of the determination of income or income from the profession as a source of zakat are as follows:

1. The verses of the Qur'an and hadith require all types of property to be paid of its zakat. Therefore, every income that is eligible for zakat is obliged to pay zakat, although the income is obtained through the profession of work or resources that are not explicitly mentioned in the Qur'an and hadith.

2. Various opinions of scholars expressed the existence of zakat income profession although using different terms. Through ijmali approach, the property of zakat objects can be developed using qiyas (analogy) method. In the current practice of zakat management, there are three approaches that can be done. The first approach, analogous to trade zakat or gold and silver zakat. Its haul (time ownership) 1 year, it means just pay zakat once a year. Its nishab (limitation) is equals with 85 grams of gold and its level 2.5 percent. The second approach is analogous to agricultural zakat. Its nishab equals with the worth of the price of $653 \mathrm{~kg}$ of grain or $524 \mathrm{~kg}$ of rice, with levels of 5 percent. There is no haul, meaning that every time he receives an income, he must pay income zakat immadiately. For example once a month. The third approach is analogous with two things at once (called qiyas syabah). Namely, for nishab analogous to zakat agriculture (worth $524 \mathrm{~kg}$ of rice) and without haul. The level is analogous to the gold and silver zakat, which is 2.5 percent.

3. From the point of fairness, the obligation of zakat on each possessed property will be very clear, compared with just establishing the obligation of zakat on certain commodities. Farmers who are currently in disadvantaged condition still have to pay zakat when the agricultural produce has reached nishab. Therefore, it would be fair if zakat is also an obligatory on the income earned by doctors, legal experts, consultants in various fields, lecturers, employees and employees who have high salaries, and other professions. In addition, the development of human life, especially in the field of economy, income activities through these skills and professions will grow and 
will become a major economic activity, as happened in the industrial countries today.

According to the LAZ IPB (2014), regarding amount of income zakat to pay, it is recommended to calculate zakat from gross income to further guard the caution and will be paid when the income is received or calculated once a year. The minimum limit or profits of zakat profession in Indonesia which has been set by BAZNAS is $653 \mathrm{~kg}$ of dry milled grain (Gabah Kering Giling) or equivalent to 3,188 million rupiah. This dry mill is equivalent to $522 \mathrm{~kg}$ of rice or equivalent to 4.39 million rupiah.. This study uses nishab 3,188 million rupiah.

Studies on Factors Affecting Preference of Zakat Payment

According to Sandhusen (2000), preference is a trait or a disere to choose, which practically indicates options or choice, thus an interest towards something. Sandhusen model explains that the decision taken by a consumer is not solely a decision influenced by internal factors such as consumer characteristics and consumer decision-making process only consumers. External factors also affect consumers in making decisions. The integration between external factors and internal factors is as Buyer's Black Box.

Several studies that have been done by some parties as a reference in material development. Wahid et al (2005) studied on awareness to pay income zakat in Malaysia using multivariate logistic regression analysis. The results of this study indicates that there are five factors that significantly affect the payment of zakat. These factors include age, marital status, education level, income level, and zakat payment mechanism through direct pay cuts.

Research conducted by Beik and Mukhlis (2012) on Economic Estimation and Determination of Zakat Potential in Indonesia by using discriminant analysis mention that the factors that significantly influence to muzaki to pay zakat is faith, sacrifice, usefulness, self-satisfaction, and institutional management of zakat. The study by Rouf (2011) which analyse the factors affecting muzakki's intention to pay zakat using the multiple regression analysis shows that the variable of trust, religiosity and income influence the public interest in paying zakat through Rumah Zakat branch Semarang. Other studies include that of Wahid et al. (2005) which found that income is significant in influencing the behavior and awareness of zakat in the society. Meanwhile, Beik (2012) highlighted the importance of institutional management of zakat in influencing muzakki to pay zakat.

This study aims to offer an area of novelty by offering a quantitative analysis of the factors affecting muzakki's preference to pay zakat though Amil institutions. The difference between this study with the previous researches is the use of Logistic regression analysis to provide evidence on the importance of factors such as religiosity, knowledge about zakat, LAZ IPB service, as well as demographic variables such as gender, marital status, income and occupation that could possibility influence the behavior of IPB employee to pay zakat through LAZ IPB.

\section{METHODOLOGY}

\section{Sampling and Data Collection}

This research was conducted at Bogor Agricultural University at IPB Dramaga campus. The population of the research is all IPB employees with income more than or equal to 3.1 million rupiahs, regardless of paying their zakat through LAZ IPB or through other channels. Zakat paid is income zakat. Data collection was done in the period from April 1st, 2014 to June 7th, 2014. Sampling technique being used in this research is purposive sampling method. From a total population of 2,044 of Muslim 
staff in IPB, there are only about 315 registered muzakki. For the purpose of this study, 32 respondents (or 10\%) are taken from the muzakki group, while another 32 respondents are taken from the nonmuzakki. Thus, this study used 64 IPB staff as sample to be considered in the analysis. Finally, a sample of 54 was obtained as a valid sample.

\section{Logistic Regression Analysis}

The data obtained were subjected to statistical analysis using logistic regression (logit). The logit model in this research is used to analyze the factors that influence muzaki in choosing the zakat institution. The logit model is derived based on the cumulative logistics opportunity function specified as follows (Juanda, 2009):

$$
\begin{aligned}
& P_{i}=F\left(Z_{i}\right)=F\left(\alpha+\beta X_{i}\right)= \\
& \frac{1}{1+e^{-(\alpha+\beta X i)}}
\end{aligned}
$$

where:

$$
\begin{aligned}
P_{i}= & \begin{array}{l}
\text { Preference of employees in } \\
\text { choosing zakat instutition }(1 \text { if }
\end{array} \\
& \text { choose LAZ IPB, 0 if not } \\
& \text { selecting LAZ IPB) } \\
\alpha= & \text { Intercept } \\
\beta= & \text { Parameter variables } \mathrm{X}_{\mathrm{i}} \\
\mathrm{X} 1= & \text { Religiousity } \\
\mathrm{X} 2= & \text { Knowledge } \\
\mathrm{X} 3= & \text { Service } \\
\mathrm{X} 4= & \text { Income } \\
\mathrm{X} 5= & \text { Age } \\
\mathrm{X} 6= & \text { Occupation } \\
\mathrm{X} 7= & \text { Marital status } \\
\mathrm{X} 8= & \text { Gender (dummy male }=1, \\
\mathrm{X} 9= & \text { Education }
\end{aligned}
$$

The odds ratio is the chance ratio of option 1 (choose LAZ IPB) towards cahnce ratio of option 2 (not selecting LAZ IPB). The odds value becomes an indicator value of muzaki inclined for selecting option 1. The bigger odds value indicates the greater muzaki's opportunity to choose
LAZ IPB. The relationship between parameters and odds ratios are:

Odds Ratio $=\frac{P_{i}}{1-P_{i}}$ where:

$$
P_{i}=\text { Chance ratio of option } 1
$$

\section{FINDINGS}

Factors Influencing Employees' Preference to Pay Income Zakat in LAZ IPB

Zakat habit behavior in every possessed properties is a noble behavior. Funds collected from zakat channeled through LAZ IPB can be useful for various social welfare development programs around the campus. Table 3 provides the estimation results from the Logit model based on the respondents' grouping in the participation of zakat through LAZ IPB. The result is reported based on a sample of 58 respondents, of which 22 are non-LAZ IPB muzakki, and 32 are LAZ IPB muzakki. 
Tabel 3. Estimation Result of Logit Model

\begin{tabular}{|c|c|c|c|c|c|}
\hline & & \multicolumn{4}{|c|}{ Predicted } \\
\hline & & \multicolumn{2}{|c|}{ Behavior } & \multirow[b]{2}{*}{ Percentage Correct } & \\
\hline \multicolumn{2}{|l|}{ Observed } & $\begin{array}{l}\text { Non UPZ } \\
\text { LAZ IPB }\end{array}$ & $\begin{array}{c}\text { UPZ LAZ } \\
\text { IPB }\end{array}$ & & \\
\hline \multirow[t]{2}{*}{ Behavior } & Non LAZ IPB & 16 & 6 & & 72.7 \\
\hline & UPZ LAZ IPB & 2 & 30 & & 93.8 \\
\hline \multicolumn{2}{|c|}{ Overall Percentage } & & & & 85.2 \\
\hline
\end{tabular}

As shown in Table 3, the estimation of parameter assumes that the model is able to classify $72.7 \%$ of the respondents who do not pay zakat through LAZ IPB. The model also can classify $93.8 \%$ from respondents who pay their zakat through LAZ IPB. Overall, this reflects that the model can explains $85.2 \%$ from all respondents who pay their zakat through LAZ IPB and nonLAZ IPB.

A comparation between the two values indicates that there is no homoscedasticity problem. Those models able to classify the total of respondents who pay zakat through LAZ IPB and who do not pay through LAZ IPB. Hosmer and
Lameshow test results is 0.203 , means that it accept the null hypothesis because it is $>0.05$ or the model is fit with the data. Nagelkerke R Square also shows 0.508, which is means that the model is able to explain the diversity of $50.8 \%$, and the rest is explained outside the model.

Next, the results of the significance of the potential factors affecting the employees' preference to pay zakat through LAZ IPB are reported in Table 4. To reiterate, the factors being considered are religiosity, knowledge, service, income, occupation, gender, and marital status.

Tabel 4. Test Results of Significance of Independent Variables

\begin{tabular}{lrlr}
\hline \multicolumn{1}{c}{ Variabel } & \multicolumn{3}{c}{ Logit Method } \\
\cline { 2 - 4 } & Parameter & P-Value & Odds ratio \\
\hline Constant & -.334 & 0.857 & 0.716 \\
Religiousity & 0.551 & 0.247 & 0.576 \\
Knowledge & 0.355 & 0.470 & 1.426 \\
Service & 0.990 & $0.046^{* *}$ & 2.692 \\
Income & 0.415 & 0.369 & 1.514 \\
Occupation & 1.968 & $0.075^{*}$ & 7.160 \\
Gender & 1.107 & 1.135 & 0.330 \\
Marital Status & 0.250 & 0.827 & 1.283 \\
& &
\end{tabular}

Based on the results reported that the service variable of LAZ IPB has p-value 0.046 and odds ratio 2.692. This shows that the service has significant effect on the real level of 5\%. Odds ration 2.692, means that the respondent's tendency with the higher score of services to pay their zakat through
LAZ IPB is 2.692 times bigger than the respondent with the lower score of service. This result is consistent with previous study from Fatah (2006) which states that the quality of management and service variables significantly affect the preference 
of employees in zakat income through BAZ Pertamina.

The occupation variable has signifcant level 0.075 and odds ratio 7.160. This shows that occupation affetcs significantly at the level of $10 \%$. The score of odds ratio of 7.160 indicates that preference of respondents who work as lecturer has possibility to pay zakat 7.160 times higher than respondents who work as administrative staff.

Reasons to Pay or Not to Pay Income Zakat through $L A Z I P B$

Table 5 below describes reasons why muzakki of LAZ IPB pay their income zakat through LAZ IPB. The most dominant reason considered by respondents is LAZ
IPB services. About 19 respondents or equals with $59.37 \%$ stated that autodebit facility of LAZ IPB gives them the convinience to pay their zakat. The income which received by employees through banking account already deducted zakat before they use for other consumption purposes. The factor of institutional professionalism is the reason for 11 respondents or equals with $34.37 \%$ of respondents to pay their zakat through LAZ IPB. The remaining $6.25 \%$ stated to choose LAZ IPB because the access is close to the location of their residence. This result is consistent with previous study of Alhasanah (2012) that stated convenient as the most important factor for respondents in choosing a particular channel or institution to pay zakat.

Table 5. Reasons to Pay Zakat through LAZ IPB

\begin{tabular}{lcc}
\hline \multicolumn{1}{c}{ Factor(s) } & Quantity $(\mathrm{N})$ & Percentage $(\%)$ \\
\hline Convinient & 19 & 59.37 \\
Accessibility & 2 & 6.25 \\
Professionalism & 11 & 34.37 \\
\hline
\end{tabular}

Source: Primary Data (2014)

Meanwhile, the main reason of $62.5 \%$ respondents who do not pay zakat through LAZ IPB is they convenient to give it directly to mustahik who living near their residences. There are about 16.67\% respondents stated that they do not know about LAZ IPB. It can be concerned by LAZ IPB to improve their service and socialization about income zakat and their existance to Bogor Agricultural University's employees.

Table 6. Reasons of non Muzakki LAZ IPB

\begin{tabular}{lcc}
\hline \multicolumn{1}{c}{ Factor(s) } & Quantity (N) & Percentage(\%) \\
\cline { 2 - 3 } & 15 & $62.5 \%$ \\
\hline Giving direct to mustahik & 2 & $8.3 \%$ \\
$\begin{array}{l}\text { Channeling to other amil } \\
\text { zakat } \text { institutuion }\end{array}$ & 3 & $12.5 \%$ \\
$\begin{array}{l}\text { Feel that not obliged to pay } \\
\text { zakat } \\
\begin{array}{l}\text { Do not know about LAZ } \\
\text { IPB }\end{array}\end{array}$ & 4 & $16.67 \%$ \\
\hline
\end{tabular}

Source: Primary Data (2014) 


\section{CONCLUSIONS}

Based on result of this study, it can be concluded that income zakat in IPB is developing within 10 years. The amount of zakat collection always increase, however there are still lack of awareness among employees about income zakat and the existance of LAZ IPB. Meanwhile, factors that significantly affecting IPB employees in channeling their zakat through UPZ LAZ IPB are service and occupation position. The reasons of IPB's employees did not pay their zakat through LAZ IPB because they pefer to pay zakat directly to mustahik, they do not know about LAZ IPB, and also they think that they are not abliged to pay zakat.

Hence, there are some suggestions from research indicating that occupation and LAZ IPB services of LAZ IPB has significant in influencing IPB's employees to pay income zakat through LAZ IPB. Zakat institution (LAZ IPB) suppose to improve their socialization to employees in work units of IPB. The socialization can be aknowldgement about zakat institution in IPB and about income zakat. Muzaki or customer of LAZ IPB stated that they choose LAZ IPB due to its convenient in autodebet facility, hence LAZ IPB can be develop their quality of zakat service in muzaki of LAZ IPB.

\section{REFERENCES}

Al Qur'an Dan Terjemahnya Special for Women. Bandung (ID): Syaamil Quran

Alhasanah IM. 2011. Analisis Diskriminan Faktor-Faktor Yang Memengaruhi Partisipasi Berzakat Beinfak dan Pemilihan Tempat Membayar Zakat (Studi Kasus: Kabupaten Bogor) [skripsi]. Bogor (ID): Institut Pertanian Bogor

Beik IS dan Mukhlis A. 2012. Kepatuhan Membayar Zakat di Bogor. $J$ alMuzara'ah.1(1):83-100.
Beik IS. 2013. Outlook Zakat Nasional 2014 Tantangan UU No 23/2011. Iqtishodia. 2013:23.

Fatah D. 2006. Faktor-faktor yang Mempengaruhi Preferensi Karyawan Musliim Pertamina dalam Membayar Zakat Profesi melalui Baituzzakah Pertamina [tesis]. Jakarta (ID): Universitas Indonesia.

Hafidhuddin D. 2002. Zakat dalam Perekonomian Modern. Jakarta (ID): Gema Insani.

Hafidhuddin D, Rahmat Pramulya. 2008. Kaya Karena Berzakat. Jakarta (ID) : Raih Asa Sukses.

Huber S dan Odilow Huber. 2012. The centrality of Religiosity Scale. Openacess Religion 2012. 3:710724.doi:10.3390/re13030710.

[IMZ] Indonesia Magnificence of Zakat. 2012. Indonesia Zakat and Development Report 2012. Jakarta (ID): IMZ.

[IPB] Institit Pertanian Bogor. 2012. Buku Keadaan Pegawai di Lingkungan Institut Pertanian Bogor Tahun 2012. Bogor (ID): IPB Pr.

Juanda B. 2009. Ekonometrika Permodelan dan Pendugaan. Bogor (ID): IPB Press.

[LAZ IPB] Lembaga Amil Zakat Institut Pertanian Bogor. 2014. Feasibilitas LAZ IPB Kepada Regulasi Zakat. Bogor (ID): LAZ IPB.

Potensi Zakat Nasional. (2013, March/April). Majalah Zakat, 6-7.

[Presiden RI]. 2014. Instruksi Presiden Republik Indonesia Nomor 3 Tahun 2014 tentang Optimalisasi Pengumpulan Zakat di Kementerian/ Lembaga, Sekretarian Jenderal Lembaga Negara, Sekretariat Jenderal Komisi Negara, dan Badan Usaha Milik Daerah melalui Badan Amil Zakat Nasional. Jakarta (ID): Sekretaris Kabinet

[Presiden RI]. 2014. Peraturan Pemerintah Republik Indonesia 
Nomor 14 Tahun 2014 tentang Pelaksanaan Undang-undang Nomor 23 Tahun 2011 tentang Pengelolaan Zakat. Jakarta (ID): Sekretaris Kabinet.

[Presiden RI dan DPR RI]. 2011. Undangundang Republik Indonesia Nomor 23 Tahun 2011 tentang Pengelolaan Zakat. Jakarta (ID): Kementerian Sekretariat Negara Republik Indonesia.

Qardhawi Y. 1993. Hukum Zakat. Volume ke-1. Harun S, Hafidhuddin D, Hasanuddin, penerjemah. Jakarta (ID): Litera Antar Nusa.

Rouf M. 2011. Analisis Faktor-faktor yang Mempengaruhi Minat Masyarakat Menbayar Zakat di Rumah Zakat Cabang Semarang [skripsi]. Semarang (ID): Institut Agama Islam Negeri Walisongo.

Wahid H, Sanep A, Mohd AMN. 2005. Kesadaran Membayar Zakat Pendapatan di Malaysia. Putrajaya (MY): Kumpulan Kajian Ekonomi dan Kewenangan Islam Pusat Pengajian Ekonomi Universiti Kebangsaan Malaysia.

Wibisono Y. 2010. RUU Zakat dan Kesejahteraan Umat [internet]. [Waktu dan tempat pertemuan tidak diketahui]. Jakarta [ID]: ; Tersedia pada:http://zonaekis.com/ruuzakat-dan-kesejahteraanumat\#more-1181
Yekti Mahanani

International Islamic University Malaysia (IIUM), Malaysia

Tanti Novianti

Bogor Agricultural University (IPB), Indonesia

tantinovianti@yahoo.com

Ranti Wiliasih

Bogor Agricultural University (IPB), Indonesia

rarantiti@gmail.com

Salina Hj. Kassim

International Islamic University Malaysia (IIUM), Malaysia

ksalina@iium.edu.my 